\title{
Regional assessment of the implementation of wheat flour fortification in the Eastern Mediterranean Region
}

\author{
Ayoub Al Jawaldeh \\ Vienna University,
}

\section{Abstract}

Background: Wheat flour fortification is a preventive food-based approach aimed at reducing vitamin and mineral deficiencies or insufficiencies and their consequences. Fortification of industrially processed wheat flour, when appropriately implemented, is a simple, inexpensive and effective strategy for supplying vitamins and minerals to large segments of the world's population.

Objectives:

The main objective of the study was to assess the current state of wheat flour fortification in the Eastern Mediterranean Region, identify common challenges and lessons learned from country experiences, outline the latest guidance on best practices, and make recommendations to advance appropriate wheat flour fortification in the Region.

Methods:

A questionnaire was designed to assess progress on the implementation of flour fortification in the Eastern Mediterranean Region according to key indicators. The questionnaire was circulated to the nutrition focal points within the Ministry of Health $(\mathrm{MOH})$ in all countries of the Region. The data were extracted, analyzed and discussed in a regional Workshop organized by WHO in 2017. Data were verified or gaps were filled through other potential resources, such as $\mathrm{MOH}$ websites, WHO, World Bank, the Food Fortification Initiative and CDC.

Results:

The study shows that flour fortification has been widely used in countries of the Eastern Mediterranean Region. Most countries (17 of 22 in the Region) have some coverage of wheat flour fortified with iron and folic acid, and this is mandatory in 11 countries. Eight countries fortify flour with B-vitamins. Fortification with vitamin $\mathrm{D}$, vitamin $\mathrm{A}$ and zinc is currently rare (two countries in each case). Quality control and monitoring of wheat flour is still a big challenge in all countries.

Conclusion and recommendations:

Considerable progress has been made in tackling micronutrient deficiencies, and wheat flour fortification has contributed to this. However, given that micronutrient deficiencies persist in the Region further progress is needed. Furthermore, countries need to review their policies and practices to ensure that they are in line with WHO guidance on best practice and that wheat flour fortification is being appropriately implemented.

\section{Introduction}

The best way to prevent micronutrient malnutrition is to ensure consumption of a balanced diet that is adequate in every nutrient. Unfortunately, this is far from being achievable since it requires universal access to adequate food and appropriate dietary habits. Hence, food fortification has the double advantage of being able to deliver nutrients to large segments of the population without requiring changes in food consumption patterns. Bread is consumed as a staple food in all countries of the Region, meaning that fortified bread is one way to reach poorer populations across the Eastern Mediterranean. 
Increased attention to the problem of micronutrient malnutrition in the Region is not only of concern to poor countries, where micronutrient deficiencies are certainly more frequent and severe among vulnerable groups and disadvantaged populations, they also represent a public health problem in some high- and upper-middle income countries, such as the Gulf Cooperation Council (GCC) countries and Iran. This is particularly true for anaemia, which evidence suggests is currently the most prevalent micronutrient deficiency in the Region and globally (1). In addition, the recent and ongoing shifts in food consumption from traditional diets to diets rich in highly processed foods are likely to adversely affect micronutrient intake and status.

The measures needed to tackle the major micronutrient deficiencies are, however, well known, and are, moreover, relatively cheap and easy to implement. The control of iodine deficiency disorders through salt iodization in the Region has successfully reduced this problem in many countries, and recently eight countries were declared free from iodine deficiencies including GCC countries, Iran, Jordan and Egypt.

Flour fortification has been widely implemented in countries of the Eastern Mediterranean. The WHO Regional Office for the Eastern Mediterranean, with support from the United Nations Children's Fund (UNICEF) and the Micronutrient Initiative (MI), launched an initiative in 1999 which subsequently led to nearly all the countries in the Region fortifying wheat flour with at least iron and folic acid by 2018.

Historically, Saudi Arabia was the first country in the Region to start with wheat flour fortification in 1970; followed by Oman in 1996, by adding folic acid to wheat flour. The support of WHO/MI Fund accelerated progress in the Region; which has been expanded with the support of the World Food Programme (WFP), GAIN, and USAID.

Cost-benefit data from several countries show that investing US\$ 1 in folic acid fortification, for example, leads to savings in the order of US\$ 12 to 48 for Chile and the United States of America, respectively (2).

\section{Situation analysis}

Malnutrition is a complex challenge for the Eastern Mediterranean Region where many countries have multiple forms of malnutrition among their populations at the same time. Populations are affected by undernutrition, including micronutrient deficiencies, and overweight, obesity and diet-related noncommunicable diseases (NCDs).

Micronutrient malnutrition is still chronic in the Region. One of the main reasons for the increased interest in this issue is the realization that micronutrient malnutrition contributes substantially to the regional burden of disease. In 2009, the Regional Nutrition Strategy and Action Plan developed by the WHO Regional Office, identified iodine, iron, folic acid, vitamin A and vitamin D and zinc deficiencies as being among the Region's most serious health risk factors (3). Micronutrient malnutrition is responsible for a wide range of non-specific physiological impairments, leading to reduced resistance to infections, metabolic disorders, and delayed or impaired physical and psychomotor development, especially in low-income countries or countries with emergencies (such as Yemen, Djibouti, Sudan, Afghanistan and Pakistan) and among the communities of refugees and internally displaced persons living in camps in Iraq, Syria, Jordan and Lebanon.

Several micronutrient deficiencies are still being reported from many countries of the Region (iron, iodine, zinc, calcium, folic acid and vitamins A and D), particularly among vulnerable groups, including children and women of childbearing age (4).

Anaemia is a persistent challenge in the Eastern Mediterranean Region (4). It is estimated that nearly half (48.6\%) of pre-school children and more than a third of women of childbearing age (37.7\%) and of pregnant women (38.9\%) in the Region were anaemic in 2011 (5). National reports of prevalence range from $7.4 \%$ to $88 \%$ in children aged $<5$ years (haemoglobin $<11 \mathrm{~g} / \mathrm{dl}$ ), $7.4-40.9 \%$ in school-aged children (haemoglobin $<12$ $\mathrm{g} / \mathrm{dl}), 16-81 \%$ in pregnant women, and 19.9-63\% among women of reproductive age (4). The highest 
prevalence of anaemia was found in Sudan for children aged $<5$ years $(88 \%)$ and pregnant women $(81 \%)$, in Oman (40.9\%) for school-aged children and in Djibouti (63\%) for women of childbearing age (4).

Vitamin A deficiency is considered a public health problem in several countries, affecting preschoolers, schoolage children and women of reproductive age. Vitamin A deficiency is highly prevalent with 0.8 million preschool-age children estimated to have night blindness and 13.2 million preschool-age children with low serum retinol levels $(<0.7 \mu \mathrm{mol} / \mathrm{l})$. Although national estimates are limited, prevalence in the Region ranges from $0.5 \%$ to $72.9 \%$ in children under 5 years old and from $2.3 \%$ to $31.5 \%$ in school age children, and go up to $40 \%$ in women of childbearing age or pregnant women in some countries (6).

Iodine deficiency is recognized as a significant public health problem in 18 countries, and one third of the population is estimated to be at risk of developing iodine deficiency disorders, which have dramatic consequences for the fetal brain and for cognitive and functional development in early childhood. National estimates of prevalence of iodine deficiency among school-aged children range from $10 \%$ to $91.9 \%$, while studies among pregnant women and women of reproductive age found rates between $18.7 \%$ and $70.5 \%$ (6).

\section{Evidence for the effectiveness of flour fortification}

Evidence from several countries shows that fortification of staple foods is associated with significant reductions in the incidence of deficiency-related conditions and improvements in the health status of the population (7).

In relation to iron, systematic reviews have shown that fortification of staple foods with iron has improved iron status in children (8), (9) and women (8), (10). However, more studies evaluating the effect of iron fortification of wheat flour on iron status and anaemia are needed. In addition, much of the experience with fortification of wheat flour with iron pre-dates the WHO recommendations on levels and compounds for flour fortification, and few of the programmes studied are in line with these recommendations (11), (12) . Nonetheless, fortifying wheat flour with iron has been shown to improve iron status among specific populations in several countries that have measured iron status before and after fortification. In addition, a 2015 systematic review of the effect of wheat flour fortification identified consistent reductions in the prevalence of low ferritin concentrations (a marker of iron deficiency) in women and more limited evidence of its effectiveness in reducing the prevalence of anaemia in women and children (12).

Studies on the effect of food fortification with folic acid on the occurrence of neural tube birth defects such as spina bifida consistently report substantial reductions in the incidence of neural tube defects after fortification. A meta-analysis of eight large population-based studies on the effect of food fortification with folic acid on neural tube defects estimated that fortification can reduce the risk by $46 \%$ (13).

\section{Results and discussion}

The study shows that flour fortification has been widely used in countries of the Eastern Mediterranean Region. Most countries (17 of 22 in the Region) have some coverage of wheat flour fortified with iron and folic acid, and this is mandatory in 11 countries. Eight countries fortify flour with B-vitamins. Fortification with vitamin $\mathrm{D}$, vitamin $\mathrm{A}$ and zinc is currently rare (two countries in each case). Quality control and monitoring of wheat flour is still a big challenge in all countries (Table 1).

The regional assessment and regular reporting from the countries shows that food fortification alone cannot correct micronutrient deficiencies when large numbers of the targeted population, either because of poverty or locality, have little or no access to the fortified food (as is the case in the rural areas of Pakistan, Afghanistan and Sudan), or when the level of micronutrient deficiency is too severe, and coincides with high prevalence of infections which increase the need for micronutrients.

The other key obstacles facing the food fortification programmes in the Region are: lack of a monitoring system, whether run by the Government or by mills, in most countries; safety practices inside the mills; technological and cost considerations which can delay the expected impacts of food fortification. Thus, proper 
food fortification programme planning not only requires assessment of its potential impact on the nutritional status of the population but also needs to take into account its practicability and sustainability in a particular context.

The demand for food fortification has increased in the countries of the Region due to the greater awareness among the population and among policymakers about the widespread prevalence and harmful effects of micronutrient malnutrition in the Region as a consequence of the changes to food systems and limited access of the public to healthy and diversified foods, especially in low income societies. Moreover, successful fortification experiences in other regions has contributed to a growing number of Eastern Mediterranean countries committing to scale up food fortification. With so much accumulated experience, food fortification is being recommended as a strategic option for controlling micronutrient malnutrition under certain conditions.

The success of a fortification programme can be measured through its public health impact and its sustainability. This can be achieved by adopting an intersectoral approach which includes, in addition to national public health authorities, a variety of sectors including research, trade, law, education, nongovernmental organizations and the commercial sector. They all should be involved in the planning and implementation of the programme. These programmes are well articulated in Jordan, Morocco, Oman, Iran and Palestine. The role and commitment of the private sector, in particular industry, is vital - as seen in Morocco and the GCC - and it is important that civil society is also involved in the national fortification programme, as has been done successfully in Pakistan. These are now fully acknowledged among UN/NGOs funded projects i.e. Sudan, Afghanistan, Djibouti and Pakistan. In few countries are the fortification programmes sustainable and supported by the Government, which is the case in Oman, Jordan and Palestine. These programmes are included in the health financing system.

During discussion with country representatives, UN agencies and NGOs during the workshop, the following common challenges for wheat flour fortification in the Region were identified:

1- Lack of political will and general low awareness of the importance of tackling micronutrient deficiencies, coupled with inadequate data on food consumption and nutrient status to inform public policy-making and monitor progress;

2- $\quad$ Coordinating different ministries and government bodies from multiple sectors, and mobilizing the private sector;

3- $\quad$ Securing sustainable funding (especially for the provision of the premix);

4- Controlling imports of wheat and/or wheat flour;

5- Expanding coverage of fortification when a substantial proportion of flour is produced by many small-scale mills;

6- $\quad$ Insufficient numbers of food inspectors and/or training for inspectors;

7- $\quad$ Shortage of equipment and the costs of long-term maintenance of equipment (e.g. feeders);

8- $\quad$ Building capacity by training mill workers, managers, inspectors etc.;

9- Evaluating the effect of fortification because it is often implemented with other micronutrient strategies (e.g. supplementation, measures to promote dietary diversity).

10- Limited research that shows the cost-benefit of flour fortification for countries in the Region (flour fortification can reduce iron deficiency and iron deficiency anaemia thus improving productivity, and has been shown to reduce neural tube defects thus lowering the economic burden on families)

Experiences from some countries of the Eastern Mediterranean Region can provide useful lessons for other countries that want to introduce or expand wheat flour fortification, and seen improvements in micronutrient status have identified several key elements for success:

1- $\quad$ Government commitment, at the highest possible level, is essential.

2- $\quad$ Strong advocacy is needed to convince the government of the importance of taking action.

3- A mandatory approach, with clear technical standards, is more likely to be effective. 
4- A multisectoral alliance, bringing together all relevant stakeholders -government, UN agencies, donors and the private sector - can help drive the process forward, provided that strong safeguards are in place to prevent and manage conflicts of interest.

5- $\quad$ Strong monitoring and enforcement systems, which combine both internal monitoring (in the mills) and external monitoring by food control inspectors, are essential.

6- $\quad$ Financial support, particularly for the provision of the premix, is sometimes necessary.

7- $\quad$ The costs of maintaining equipment can be reduced by negotiating with suppliers of equipment to provide an after-sales warranty for repairs, for a very small additional initial cost.

\section{Conclusions and recommendations}

While efforts to improve vitamin and mineral status should always be based on transforming food systems to improve access to, and availability of, varied and good quality diets, fortification of widely distributed and consumed foods can also help improve the nutritional status of a large proportion of the population. Because bread is a staple food in the Region and is eaten in large quantities, wheat flour used in bread baking is an ideal carrier. Fortification of industrially-processed wheat flour, when appropriately implemented, is a simple, inexpensive and effective strategy for supplying vitamins and minerals to the diets of large segments of the Region's population.

Nonetheless, further action is needed to expand coverage of wheat flour fortification and ensure that it is effective. A 2017 workshop on best practices of wheat flour fortification identified lessons learned from country experience and proposed a number of recommendations for the Region:

- National decision-makers should be responsible for defining an appropriate fortification strategy for their specific national context.

- $\quad$ Updated national data are urgently needed to better inform policy and programmes in countries. Strong systems for gathering reliable data on food consumption, food composition and nutrition status are needed.

- Countries are encouraged to use cost-benefit tools with existing data to calculate the costs of nonaction and of fortification for their country situation and estimate the economic benefits of fortification.

- Countries are urged to follow WHO's Recommendations on wheat and maize flour fortification: interim consensus statement including recommendations on appropriate micronutrient levels and compounds.

- A mandatory approach is likely to be most effective through primary legislation, food regulations or technical standards, which should apply to both imported and domestically produced wheat flour, with controls enforced at the point of importation.

- $\quad$ To avoid trade issues, standards should be based on scientific evidence and represent a proportionate response to a public health problem; countries are encouraged to share draft standards with the members of the World Trade Organization and trading partners.

- $\quad$ Regulatory measures on food fortification should always include provisions to prevent or minimize the risk of excessive intake of vitamins and minerals. Countries are encouraged to form an advisory group responsible for all forms of micronutrient interventions in order to monitor dietary intakes, coordinate efforts to minimize the risk of excessive intakes, and advise on appropriate interventions.

- $\quad$ Monitoring and enforcement systems need both internal monitoring by the food industry through quality assurance processes and external monitoring by the government (at the appropriate level) through food inspections and technical auditing.

- Countries are encouraged to regularly report the prevalence of micronutrient deficiencies or insufficiencies, particularly in the most vulnerable population groups. Reporting prevalence data disaggregated into mild, moderate and severe levels of deficiency, where possible, may be useful. Countries are encouraged to monitor and assess coverage of food fortification, and when high coverage of high quality, fortified wheat flour has been sustained over time they should assess the expected effect on nutritional status (if regular nutrition surveillance is not in place). 
- $\quad$ Food fortification programmes should be designed from the outset to be sustainable, and should only be initiated with short-term funding if a plan for sustainable funding in the long term has been developed.

- Member States are encouraged to learn from the experiences of other countries, and cooperation at the regional level should be expanded in order to exchange information and lessons learned. Countries with similar levels of micronutrient deficiencies and similar needs are encouraged to collaborate to pursue a harmonized approach.

- A regional alliance on micronutrients would help facilitate communication and the WHO Regional Office will facilitate its establishment.

- $\quad$ Further support or guidance from WHO would be welcome about the methodology for assessing micronutrient deficiencies, best practices for wheat flour fortification with vitamin $\mathrm{D}$, procurement or local production of fortification premix, anaemia control, establishment of nutrition surveillance systems, recommended procedures for quality control/assurance, and how to measure outcomes and health impact. 
Table 1 Summary of wheat flour fortification status in the Eastern Mediterranean Region

\begin{tabular}{|c|c|c|c|c|c|c|c|}
\hline \multirow{2}{*}{$\begin{array}{l}\text { Countr } \\
\mathbf{y}\end{array}$} & \multirow[t]{2}{*}{ Fortification status } & \multicolumn{5}{|l|}{ Nutrients } & \multirow{2}{*}{$\begin{array}{l}\text { Estimated } \\
\text { coverage } \\
\text { (according to } \\
\text { estimates of the } \\
\text { Food } \\
\text { Fortification } \\
\text { Initiative) }\end{array}$} \\
\hline & & $\begin{array}{l}\text { Iron (level } \\
\text { and type } \\
\text { where } \\
\text { available) }\end{array}$ & $\begin{array}{l}\text { Folic } \\
\text { acid } \\
\text { (level) }\end{array}$ & $\begin{array}{l}\text { Vitam } \\
\text { in D }\end{array}$ & $\begin{array}{l}\text { B } \\
\text { vitam } \\
\text { ins }\end{array}$ & Other & \\
\hline $\begin{array}{l}\text { Afghan } \\
\text { istan }\end{array}$ & $\begin{array}{l}\text { Voluntary, but legislation } \\
\text { in process }\end{array}$ & 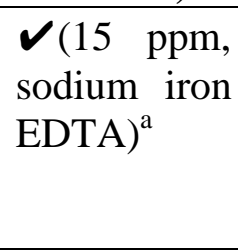 & $\begin{array}{l}\boldsymbol{V}(1 \\
\mathrm{ppm})^{\mathrm{a}}\end{array}$ & $x$ & B12 & $\begin{array}{l}\text { Vitami } \\
\text { n A }\end{array}$ & $\begin{array}{l}\text { Only } 26 \% \text { of } \\
\text { flour is produced } \\
\text { in industrial } \\
\text { mills, only } 2 \% \text { of } \\
\text { which is fortified }\end{array}$ \\
\hline Bahrain & Mandatory & $\begin{array}{l}\nu(60 \mathrm{ppm}, \\
\text { elemental } \\
\text { iron })^{\mathrm{b}}\end{array}$ & $\begin{array}{l}\mathcal{V}(1.5 \\
\mathrm{ppm}^{\mathrm{b}}\end{array}$ & $x$ & $x$ & $x$ & $\begin{array}{l}\text { All of the flour is } \\
\text { produced in } \\
\text { industrial mills, } \\
90 \% \text { of which is } \\
\text { fortified }\end{array}$ \\
\hline $\begin{array}{l}\text { Djibout } \\
\mathrm{i}\end{array}$ & Mandatory & $\begin{array}{l}\checkmark(60 \mathrm{ppm}, \\
\text { electrolytic } \\
\text { iron })^{\mathrm{c}}\end{array}$ & $\begin{array}{l}\mathcal{V}(1.5 \\
\mathrm{ppm})^{\mathrm{c}}\end{array}$ & $x$ & $x$ & Zinc & $\begin{array}{l}\text { All flour is } \\
\text { industrially } \\
\text { milled by } 1 \text { mill , } \\
95 \% \text { of which is } \\
\text { fortified }\end{array}$ \\
\hline Egypt & $\begin{array}{l}\text { Stalled since 2011, } \\
\text { discussions ongoing }\end{array}$ & $\boldsymbol{V}(30 \mathrm{ppm})^{\mathrm{d}}$ & $\begin{array}{l}\boldsymbol{V} \\
(\mathrm{N} / \mathrm{A})\end{array}$ & $x$ & $x$ & $x$ & $\begin{array}{l}\text { All flour is } \\
\text { produced in } \\
\text { industrial mills, } \\
\text { but none is } \\
\text { fortified }\end{array}$ \\
\hline $\begin{array}{l}\text { Iran, } \\
\text { Islamic } \\
\text { Republi } \\
\text { c of }\end{array}$ & Mandatory since 2007 & $\boldsymbol{V}(30 \mathrm{ppm})^{\mathrm{b}}$ & $\begin{array}{l}\boldsymbol{V}(1.5 \\
\mathrm{ppm}^{\mathrm{b}}\end{array}$ & $\begin{array}{l}\text { Propos } \\
\text { al in } \\
\text { develo } \\
\text { pment }\end{array}$ & $x$ & $\begin{array}{l}\text { Zinc: } \\
\text { propos } \\
\text { al in } \\
\text { develo } \\
\text { pment }\end{array}$ & $\begin{array}{l}\text { All flour is } \\
\text { produced in } \\
\text { industrial mills, } \\
100 \% \text { of which is } \\
\text { estimated to be } \\
\text { fortified; lower } \\
\text { coverage } \\
\text { other mills }\end{array}$ \\
\hline Iraq & $\begin{array}{l}\text { Mandatory since 2008, } \\
\text { government provision of } \\
\text { premix stalled since } 2014\end{array}$ & $\begin{array}{l}\boldsymbol{\nu}(30 \text { ppm } \\
\text { as ferrous } \\
\text { sulfate/60 } \\
\text { ppm } \\
\text { electrolytic } \\
\text { iron })^{\text {c,d }}\end{array}$ & $\begin{array}{l}\boldsymbol{V}(2.1 \\
\mathrm{ppm})^{\mathrm{c}}\end{array}$ & $x$ & $x$ & $x$ & $\begin{array}{l}\text { All flour is } \\
\text { produced in } \\
\text { industrial mills, } \\
\text { but premix } \\
\text { provision has } \\
\text { stalled recently }\end{array}$ \\
\hline Jordan & Mandatory since 2002 & 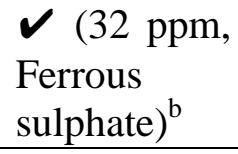 & $\begin{array}{l}\boldsymbol{\mathcal { V }}(1 \\
\mathrm{ppm})^{\mathrm{b}}\end{array}$ & $\checkmark$ & $\begin{array}{l}\text { B1, } \\
\text { B2, } \\
\text { B3, }\end{array}$ & $\begin{array}{l}\text { Zinc, } \\
\text { vitami } \\
\mathrm{n} \quad \mathrm{A},\end{array}$ & $\begin{array}{l}\text { About } 93 \% \text { of } \\
\text { Jordan's wheat } \\
\text { flour production }\end{array}$ \\
\hline
\end{tabular}




\begin{tabular}{|c|c|c|c|c|c|c|c|}
\hline & & & & & $\begin{array}{l}\text { B12, } \\
\text { B6 }\end{array}$ & $\begin{array}{l}\text { vitami } \\
\text { n D }\end{array}$ & is fortified \\
\hline Kuwait & Mandatory & $\begin{array}{l}\boldsymbol{V}(30 \mathrm{ppm} \\
\text { as ferrous } \\
\text { sulfate/60 } \\
\text { ppm } \\
\text { electrolytic }^{\mathrm{c}} \\
\text { iron })^{\mathrm{d} d}\end{array}$ & $\begin{array}{l}\boldsymbol{V} \\
(1.75 \\
\mathrm{ppm})^{\mathrm{c}}\end{array}$ & $x$ & $\begin{array}{l}\text { B1, } \\
\text { B2, } \\
\text { B3 }\end{array}$ & $x$ & $\begin{array}{l}\text { All flour is } \\
\text { produced in } \\
\text { industrial mills, } \\
100 \% \text { of which is } \\
\text { estimated to be } \\
\text { fortified }\end{array}$ \\
\hline $\begin{array}{l}\text { Lebano } \\
\mathrm{n}\end{array}$ & $\begin{array}{l}\text { No mandatory or voluntary } \\
\text { fortification }\end{array}$ & 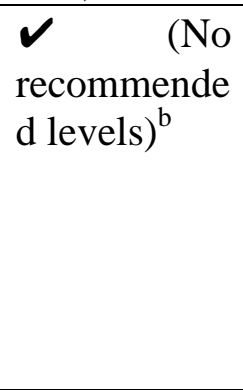 & $v$ & $x$ & $\begin{array}{l}\text { B1, } \\
\text { B2, } \\
\text { B3 }\end{array}$ & $x$ & $\begin{array}{lr}\text { All flour } & \text { is } \\
\text { produced in } \\
\text { industrial mills } \\
\text { and none is } \\
\text { fortified (one } \\
\text { mill may be } \\
\begin{array}{l}\text { voluntarily } \\
\text { fortifying) }\end{array}\end{array}$ \\
\hline Libya & $\begin{array}{l}\text { No mandatory or voluntary } \\
\text { fortification }\end{array}$ & $x$ & $x$ & $x$ & $x$ & $x$ & $\begin{array}{l}\text { No flour is } \\
\text { reported to be } \\
\text { fortified }\end{array}$ \\
\hline $\begin{array}{l}\text { Morocc } \\
\mathrm{o}\end{array}$ & Mandatory since 2006 & $\boldsymbol{V}(45 \mathrm{ppm})^{\mathrm{b}}$ & $\begin{array}{l}\boldsymbol{v} \\
(\mathrm{N} / \mathrm{A})\end{array}$ & $x$ & $x$ & $x$ & $\begin{array}{l}\text { All flour is } \\
\text { produced in } \\
\text { industrial mills, } \\
70 \% \text { of which is } \\
\text { estimated to be } \\
\text { fortified }\end{array}$ \\
\hline $\begin{array}{l}\text { Occupi } \\
\text { ed } \\
\text { Palestin } \\
\text { ian } \\
\text { territor } \\
\text { y } \\
\end{array}$ & $\begin{array}{l}\text { Mandatory standard in } \\
\text { place }\end{array}$ & 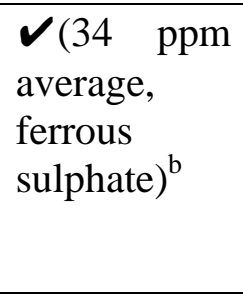 & $\begin{array}{l}\boldsymbol{V}(1.5 \\
\mathrm{ppm})^{\mathrm{b}}\end{array}$ & $\checkmark$ & $\begin{array}{l}\text { B1, } \\
\text { B2, } \\
\text { B6, } \\
\text { B12, } \\
\text { B3 }\end{array}$ & $\begin{array}{l}\text { Vitami } \\
\text { n A, } \\
\text { Zinc }\end{array}$ & $\begin{array}{l}\text { All flour is } \\
\text { produced in } \\
\text { industrial mills, } \\
100 \% \text { of which is } \\
\text { estimated to be } \\
\text { fortified }\end{array}$ \\
\hline Oman & Mandatory since 1996 & $\begin{array}{l}\boldsymbol{V}(30 \\
\text { ppm })^{\mathrm{d}} /(120 \\
\text { ppm, } \\
\text { multiple } \\
\text { compounds } \\
\text { allowed })^{\mathrm{c}}\end{array}$ & $\begin{array}{l}\boldsymbol{V}(1.5 \\
\mathrm{ppm})^{\mathrm{c}}\end{array}$ & $x$ & $x$ & $x$ & $\begin{array}{l}\text { All flour is } \\
\text { produced in two } \\
\text { industrial mills, } \\
89 \% \text { of which is } \\
\text { estimated to be } \\
\text { fortified }\end{array}$ \\
\hline $\begin{array}{l}\text { Pakista } \\
\mathrm{n}\end{array}$ & $\begin{array}{l}\text { Mandatory in some } \\
\text { provinces, national roll-out } \\
\text { planned }\end{array}$ & $\boldsymbol{V}(15 \mathrm{ppm})^{\mathrm{a}}$ & $\begin{array}{l}\boldsymbol{V}(1 \\
\mathrm{ppm})^{\mathrm{a}}\end{array}$ & $x$ & B12 & Zinc $^{a}$ & $\begin{array}{l}60 \% \text { of flour is } \\
\text { produced in } \\
\text { industrial mills, } \\
2 \% \text { of which is } \\
\text { estimated to be } \\
\text { fortified }\end{array}$ \\
\hline Qatar & Voluntary fortification & $\begin{array}{l}\boldsymbol{V}(30 \quad \mathrm{ppm} \\
\text { as ferrous } \\
\text { sulfate/60 } \\
\text { ppm } \\
\text { electrolytic }^{\mathrm{c}} \\
\text { iron })^{\mathrm{d} d}\end{array}$ & $\begin{array}{l}\boldsymbol{V} \\
(1.75 \\
\operatorname{ppm})^{\mathrm{c}}\end{array}$ & $x$ & $\begin{array}{l}\text { B1, } \\
\text { B2, } \\
\text { B3 }\end{array}$ & $x$ & $\begin{array}{l}\text { All flour is } \\
\text { produced in two } \\
\text { industrial mills, } \\
90 \% \text { of which is } \\
\text { estimated to be } \\
\text { fortified }\end{array}$ \\
\hline
\end{tabular}




\begin{tabular}{|c|c|c|c|c|c|c|c|}
\hline $\begin{array}{l}\text { Saudi } \\
\text { Arabia }\end{array}$ & Mandatory & $\boldsymbol{V}(36 \mathrm{ppm})^{\mathrm{c}}$ & $\begin{array}{l}\boldsymbol{V} \\
(1.75 \\
\mathrm{ppm})^{\mathrm{c}}\end{array}$ & $\begin{array}{l}550 \\
\mathrm{IU} / \mathrm{kg}\end{array}$ & $\begin{array}{l}\text { B1, } \\
\text { B2, } \\
\text { B3 }\end{array}$ & $x$ & $\begin{array}{ll}\text { All flour } & \text { is } \\
\text { produced } & \text { in } \\
\text { industrialized } & \\
\text { mills, } 100 \% & \text { of } \\
\text { which } & \text { is } \\
\text { estimated to be } \\
\text { fortified }\end{array}$ \\
\hline $\begin{array}{l}\text { Somali } \\
\text { a }\end{array}$ & $\begin{array}{l}\text { No mandatory or voluntary } \\
\text { fortification }\end{array}$ & $x$ & $x$ & $x$ & $x$ & $x$ & $\begin{array}{lr}\text { All flour } & \text { is } \\
\text { produced in one } \\
\text { industrial } \\
\text { but mill } \\
\text { fortified }\end{array}$ \\
\hline Sudan & $\begin{array}{l}\text { Voluntary fortification by } \\
\text { one mill. Law for } \\
\text { mandatory fortification in } \\
\text { development }\end{array}$ & $\begin{array}{l}\boldsymbol{\nu} \text { voluntary } \\
(\mathrm{N} / \mathrm{A})\end{array}$ & $\begin{array}{l}\boldsymbol{\gamma} \\
\text { volunt } \\
\text { ary } \\
\text { (N/A) }\end{array}$ & $x$ & $x$ & $x$ & $\begin{array}{l}80 \% \text { of flour is } \\
\text { produced in } \\
\text { industrial mills, } \\
40 \% \text { of which is } \\
\text { estimated to be } \\
\text { fortified }\end{array}$ \\
\hline $\begin{array}{l}\text { Syrian } \\
\text { Arab } \\
\text { Republi } \\
\text { c }\end{array}$ & Voluntary fortification & $\begin{array}{l}\boldsymbol{\nu}(30 \mathrm{ppm} \\
\text { ferrous } \\
\text { sulfate })^{\mathrm{d}}\end{array}$ & $\checkmark$ & $x$ & $x$ & $x$ & $\begin{array}{l}80 \% \text { of flour is } \\
\text { produced in } \\
\text { industrial mills, } \\
5 \% \text { of which is } \\
\text { estimated to be } \\
\text { fortified }\end{array}$ \\
\hline Tunisia & $\begin{array}{l}\text { No national fortification } \\
\text { programme, but the policy } \\
\text { is being reconsidered }\end{array}$ & $x$ & $x$ & $x$ & $x$ & $x$ & $\begin{array}{l}\text { All flour } \\
\text { produced } \\
\text { industrial mills } \\
\text { but none is } \\
\text { fortified }\end{array}$ \\
\hline $\begin{array}{l}\text { United } \\
\text { Arab } \\
\text { Emirate } \\
\text { s }\end{array}$ & Voluntary fortification & $\begin{array}{l}\boldsymbol{V}(30 \\
\mathrm{ppm})^{\mathrm{c}, \mathrm{d}}\end{array}$ & $\begin{array}{l}\boldsymbol{V} \\
(1.75 \\
\mathrm{ppm})^{\mathrm{c}}\end{array}$ & $x$ & $\begin{array}{l}\text { B1, } \\
\text { B2, } \\
\text { B3 }\end{array}$ & $x$ & $\begin{array}{l}\text { All flour is } \\
\text { produced in } \\
\text { industrial mills, } \\
90 \% \text { of which is } \\
\text { estimated to be } \\
\text { fortified }\end{array}$ \\
\hline Yemen & Mandatory fortification & $\begin{array}{l}\boldsymbol{V}(30 \mathrm{ppm} \\
\text { as ferrous } \\
\text { sulfate/60 } \\
\text { ppm } \\
\text { electrolytic } \\
\text { iron })^{\mathrm{c}, \mathrm{d}}\end{array}$ & $\checkmark$ & $x$ & $x$ & $x$ & $\begin{array}{l}\text { All flour is } \\
\text { produced in } \\
\text { industrial mills, } \\
100 \% \text { of which is } \\
\text { estimated to be } \\
\text { fortified }\end{array}$ \\
\hline
\end{tabular}

EDTA = ethylenediaminetetraacetic acid; N/A = not available.

${ }^{a}$ Proposed levels for new standard. Information from country representative.

${ }^{\mathrm{b}}$ Source: country representative.

${ }^{\mathrm{c}}$ Source: Food Fortification Initiative.

${ }^{\mathrm{d}}$ Source: (14). 


\section{References}

[1] World Health Organization. Global Nutrition Targets 2025: Anaemia policy brief. Geneva: WHO; 2014.

[2] Llanos A, Hertrampf E, Cortes F, Pardo A, Grosse S, Uauy R. Cost-effectiveness of a folic acid fortification program in Chile. Health Policy. 2007 Oct; 83(2-3): p. 295-303.

[3] World Health Organization. Regional Strategy on Nutrition 2010-2019. Cairo: WHO Regional Office for the Eastern Mediterranean; 2009.

[4] Nasreddine L, Ayoub JJ, Al Jawaldeh A. Review of the nutrition situation in the Eastern Mediterranean Region. Eastern Mediterranean Health Journal. 2018; 24(1): p. 77-91.

[5] World Health Organization. The Global Prevalence of Anaemia in 2011. Geneva: WHO; 2015.

[6] Al Jawaldeh A, Peña-Rosas JP, McColl K, Johnson Q, Nasreddine L. Wheat Flour Fortification in the Eastern Mediterranean Region. Cairo: WHO Regional Office for the Eastern Mediterranean; Forthcoming.

[7] World Health Organization. Guideline: fortification of maize flour and corn meal with vitamins and minerals.. Geneva: WHO; 2016.

[8] Das J, Salam R, Kumar R, Bhutta Z. Micronutrient fortification of food and its impact on woman and child health: a systematic review. Syst Rev. 2013; 23(2): p. 67.

[9] Athe R, Rao M, Nair K. Impact of iron-fortified foods on Hb concentration in children (>

[10] Gera T, Sachdev H, Boy E. Effect of iron-fortified foods on hematologic and biological outcomes: systematic review of randomized controlled trials. Am J Clin Nutr. 2012 Aug; 96(2): p. 309-24.

[11] Hurrell R, Ranum P, de Pee S, Biebinger R, Hulthen L, Johnson Q. Revised recommendations for iron fortification of wheat flour and an evaluation of the expected impact of current national wheat flour fortification programs. Food Nutr Bull. 2010 Mar; 31(1): p. S7-21.

[12] Pachón H, Spohrer R, Mei Z, Serdula M. Evidence of the effectiveness of flour fortification programs on iron status and anemia: a systematic review. Nutr Rev. 2015 Nov; 73(11): p. 780-95.

[13] Blencowe H, Cousens S, Modell B, Lawn J. Folic acid to reduce neonatal mortality from neural tube disorders. Int J Epidemiol. 2010 Apr; 39(Suppl 1): p. i110-21.

[14] Ministry of Health. Annual Health Sector Performance Report. Primary Health Care. Government sector. \% children with anemia - child screening data by health center 2012. [Online].; 2012 [cited 2018 October 17. Available from: https://www.moh.gov.bh/Content/Files/Publications/statistics/HS2015/PDF/Chapters/Primary\%20Healt $\underline{\mathrm{h} \% 20 \mathrm{Care} \text { gov\%20sector_2015.pdf. }}$ 